\title{
Effect of Pre-Treatments on Wear Index of Varnished Wood Plastic Composites (WPC) With Pigmented
}

\author{
Turgay ÖZDEMIR ${ }^{1 *}$ Fatih MENGELOĞLU ${ }^{2} \quad$ Engin Derya GEZER $^{1}$ \\ ${ }^{1 *}$ Karadeniz Technical University, Faculty of Forestry, Forest Industry Engineering, Trabzon, Turkey \\ ${ }^{2}$ Kahramanmaras Sütçü İmam University, Faculty of Forestry, Forest Industry Engineering, Kahramanmaraş, Turkey
}

How to cite: Özdemir, T., Mengeloğlu, F. \& Gezer, E.D. (2020). Effect of Pre-Treatments on Wear Index of Varnished Wood Plastic Composites (WPC) With Pigmented. J. Anatolian Env. and Anim. Sciences, 5(5), 858-862.

Atıf yapmak için: Özdemir, T., Mengeloğlu, F. \& Gezer, E.D. (2020). Pigmentli Vernikli Ahşap Plastik Kompozitlerin (WPC) Aşınma İndeksi Üzerine Ön İşlemlerin Etkisi. Anadolu Çev. ve Hay. Dergisi, 5(5), 858-862.

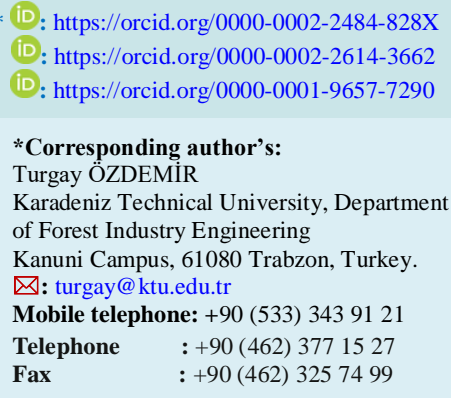

\begin{abstract}
The utilization and usage areas of the wood plastic composites (WPC) have increased over the years. In addition, the importance of wood plastic composites produced by adding pigments has increased in terms of usage area. To be able to increase the coating ability of plastics, different pre-treatment had been used and some improvements were achieved. It is the purpose of this study to determine the wear index in abrasion of the WPC with pigmented using various coating and pre-treatments. For this purpose, it was used 2 different coating types (acrylic and cellulosic based) and 4 different pretreatments (sanding, acid treatment, UV, microwave). WPC with pigmented were manufactured and samples after various pretreatment and coating were prepared. The adhesion strength values were determined after coating. The results showed that pre-treatments used in this project affected the wear index. Acrylic based coating gave the best results of wear index in abrasion.
\end{abstract}

Keywords: Acrylic varnish, Coating properties, Wear index, Wood plastic composites.

\section{Pigmentli Vernikli Ahşap Plastik Kompozitlerin (WPC) Aşınma İndeksi Üzerine Ön İşlemlerin Etkisi}

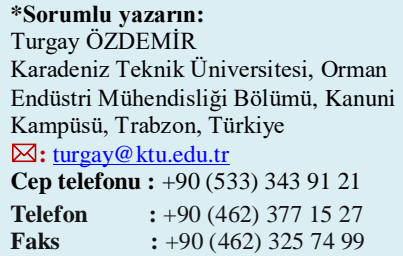

Öz: Ahşap plastik kompozitlerin (WPC) kullanım ve kullanım alanları yıllar içinde artmıştır. Ayrıca pigment ilavesiyle üretilen ahşap plastik kompozitlerin kullanım alanı açısından önemi artmıştır. Plastiklerin kaplama kabiliyetini artırabilmek için farklı ön işlemler kullanılmış ve bazı iyileştirmeler yapılmıştır. Bu çalışmanın amacı, çeşitli kaplama ve ön işlemler kullanılarak WPC'nin pigmentli aşınmasındaki aşınma indeksini belirlemektir. Bu amaçla 2 farklı kaplama tipi (akrilik ve selülozik esaslı) ve 4 farklı ön işlem (kumlama, asit muamelesi, UV, mikrodalga) kullanılmıştır. Pigmentli WPC üretildi ve çeşitli ön işlem ve kaplamalardan sonra numuneler hazırlandı. Kaplama sonrası yapışma mukavemeti değerleri belirlenmiştir. Sonuçlar, bu çalışmada kullanılan ön işlemlerin aşınma endeksini etkilediğini gösterdi. Akrilik esaslı kaplama, aşındırmada en iyi aşınma indeksi sonuçlarını vermiştir.

Anahtar kelimeler: Așınma indeksi, Ahșap plastik kompozitler, Akrilik vernik, Kaplama özellikleri. 


\section{INTRODUCTION}

Plastics are widely used in all areas of our lives. In the last century, the developments in polymer chemistry have made polymers used in our daily life and almost every part of the industry, depending on the reasons such as the lifestyle consumption habits of the developing and changing society. When the plastics are thrown away, they remain in nature for a long time without rotting, rusting, dissolving and biodegradable. Some plastics can remain in nature for 700 years. It causes contamination of water and soil. It harms the creatures in the waters and even causes their deaths. Plastics are materials that are solid at normal temperature and can be shaped or molded by different methods using pressure and temperature. Polymerization is the bonding of similar molecules that make up the polymer chain.

The production and use of wood plastic composites (WPC) continue to increase. One of the important problems encountered with the use of WPC is the color changes seen on the surfaces of the materials. Color-changed thermoplastic parts must be replaced, or their surfaces painted. However, it is extremely difficult to paint thermoplastics, especially polyethylene (PE) and polypropylene (PP) surfaces, which are called polyolefin, due to their low surface energies. Within the scope of this study, the dyeability of the surfaces of WPC materials, whose usage is increasing, was investigated (Novak and Florian, 2001).

UV lamps between $250-400 \mathrm{~nm}$ are commonly used to change and improve the surface properties of polymer surfaces (Ryntz, 1998). Generally, UV treatment is applied in the presence of oxygen and ozone in the environment and in the presence or absence of another photo initiator. After the energy carrier (photon) activates the chemical species, it replaces the hydrogen atom in the polymer chain, resulting in free radicals. Chemical species follow two pathways of crosslinking and fragmentation (Ryntz, 1994). Benzophenone (BP) is most commonly used as photo initiator. This is due to the fact that BP absorbs UV light at wavelengths at 340-360nm and excitation / activation occurs rapidly with removal of hydrogen from the polymer in singlet and triplet state to form free radicals (Ranby et al., 1999). Free radicals react with applied chemicals (paint, varnish, etc.) and provide a better adhesion. Studies on the determination of surface characteristics of wood plastic composites are quite limited. Clemons et al. (1999) described the outer-middle layer morphology that occurs in injection-pressed and extruded wood polymer composites. It has been found that in composites produced by injection, the direction of the fibers in the middle layer is perpendicular and in the outer layers the fibers are oriented parallel to the flow direction (Clemons et al., 1999).

In addition, they found that the fiber volume ratio in the middle layer was higher than in the outer layer (Yang and Ranby, 1997). Processing parameters also affect the outer-middle layer morphology. Low temperature slow processing speed causes thick outer layer formation, high temperature high processing speed causes thin outer layer formation (Fu et al., 1999).

Similarly, the extrusion process leads to differences in outer-middle layer morphology and dehumidification properties. The surface of the wood plastic composite produced by extrusion shows that it has higher density and more fiber connections than the middle layer (Barbosa and Kenny, 2000). In addition, planed wood composites contain much more wood than wood plastic composites produced either by extrusion or injection. Therefore, in general, it appears that the nature of wood plastic composites depends on processing conditions, sampling depth, and sample preparation method.

For this purpose, it was aimed to determine the adhesion strength values of wood plastic composites after pre-treatment.

\section{MATERIALS AND METHODS}

In this study; High density polyethylene (YYPE_ $\mathrm{S}$ 0464, PETKIM) found in the laboratories of Kahramanmaraş Sütçü İmam University, Faculty of Forestry, Forest Industry Engineering Department was used as polymeric material. As lignocellulosic filler, band saw wastes were obtained from sawmills processing red pine timber in Kahramanmaraş industry.

Waste of band saw was collected from sawmills processing red pine timber in the Kahramanmaraş industry. These provided red pine wastes were first grinded with the help of the grinding machine shown in Figure 14 (a), then they were sized with the help of a shaker sieve and passed through a 40 mesh $(0.400 \mathrm{~mm})$ sieve and remained on a 60 mesh $(0.250 \mathrm{~mm})$ sieve. Lignocellulosic filler, red pine wood floors were prepared by drying at $103 \pm 20 \mathrm{C}$ for 24 hours before production.

The quantities of materials to be used in thermoplastic composite production are given in Table 1.

Table 1. Trial design for the production of thermoplastic composites.

\begin{tabular}{ccccccc}
\hline $\begin{array}{c}\text { Sample } \\
\text { Code }\end{array}$ & $\begin{array}{c}\text { Polymer } \\
\text { Amount }(\%)\end{array}$ & $\begin{array}{c}\text { Lignocellulosic } \\
\text { Filler Amount }(\%)\end{array}$ & $\begin{array}{c}\text { MAPE } \\
(\%)\end{array}$ & $\begin{array}{c}\text { Zinc Sterate } \\
(\%)\end{array}$ & $\begin{array}{c}\text { Waks } \\
(\%)\end{array}$ & $\begin{array}{c}\text { Iron Oxide } \\
(\%)\end{array}$ \\
\hline TE & 44 & 50 & 2 & 2 & 2 & 2 \\
\hline
\end{tabular}

Production of HDPE Based Composites: The production of HDPE-based composites was carried out according to the scheme given in Figure 1. 


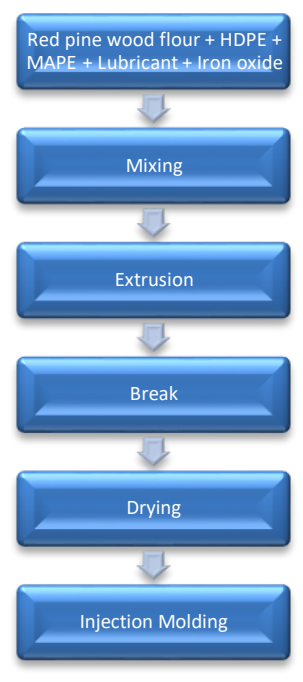

Figure 1. Composite manufacturing workflow.

Pre-Processing Samples: Before painting processes, some pre-treatments were carried out on WPC plates to determine their effects on their painting performance. These pretreatments are mechanical etching, chemical etching (diluted acid treatment), ultraviolet (UV) light and microwave applications.

Mechanical abrasing: Sanding process was carried out as mechanical abrasion. Examples; They were subjected to two different sanding processes with 60 and 80 numbered sandpaper. These samples are coded Z60 (sanded with $60 \mathrm{nl}$ sandpaper) and Z80 (sanded with no 80 sandpaper).

Chemical etching: Two different concentrations of peracetic acid, $5 \%$ and $10 \%$, were applied as chemical etching. These samples were coded as PA5 (samples treated with $5 \%$ concentration of peracetic acid) and PA10 (10\% concentration treated samples).

Ultraviolet (UV) Light: Composite samples were applied in two different UV applications as 10 and 20 minutes.

Microwave: Microwave application was applied at two different times of 15 and 30 seconds. Microwave application was carried out in the microwave oven purchased under the project.

Painting of Pre-Treated and Unapplied WPC Sheet Samples: In order to determine the painting performance of WPC boards, painting processes were carried out using different paints on pre-treated and unprocessed surfaces. For this purpose, 4 different paint applications which are mostly used in the literature and industrially were selected. These paints are polyurethane (two-component), acrylic (two-component), synthetic (one-component) and water-based (one-component) paints, and their application is based on the manufacturer's mixture recommendations.

Paint applications were carried out according to the spraying method, using a normal pressure bottom-tank varnish gun with a spray tip opening of $1.8 \mathrm{~mm}$, two layers of filling and single layer topcoat application with 125-150 gr paint per $\mathrm{m} 2$. After the paint application, all samples were kept in the air conditioning room after they were completely dried.

Wear Index Test: In order to determine the weight loss in abrasion, 5 samples of 100x100x7 mm of each varnish were used and made in accordance with ASTM D 4060-10 principles. According to this; the wear index (1), weight loss (2) and the amount of wear in each cycle (3) were determined on the samples. For this purpose, the weights of the samples before and after wear resistance were determined at a sensitivity of $\pm 0.01 \mathrm{~g}$.

The wear index I is calculated with the help of the following equation:

$I=\frac{(A-B) 1000}{C}$

Here:

$\mathrm{A}=$ Weight of sample before abrasion test, $\mathrm{g}$,

$\mathrm{B}=$ Weight, $\mathrm{g}$, of the sample after the wear test

$\mathrm{C}=$ Number of revolutions recorded in wear.

Coding Samples: The samples obtained were coded as follows.

TED-Z60 60 no. Sanded

TED-Z80 80 no. Sanded

TED-UV10 UV-treated for 10 minutes

TED-UV20 UV-treated for 20 minutes

TED-MD15 15 seconds microwaved

TED-MD30 15 seconds microwaved

TED-PA5 5\% peracetic acid applied

TED-PA10 5\% peracetic acid applied

\section{FINDINGS}

Wear Index: Average abrasion resistance results are given in Table 2 below according to varnish types.

Table 2. Abrasion results

\begin{tabular}{lcc} 
Table 2. Abrasion results & \\
\hline TED & Water based & Acrylic \\
\hline Control & 0,6000 & 0,4333 \\
MD15 & 0,7667 & 0,5667 \\
MD30 & 0,9000 & 0,3667 \\
UV10 & 0,8333 & 0,5000 \\
UV20 & 0,5333 & 0,5000 \\
PA5 & 0,7000 & 0,4667 \\
PA10 & 0,6333 & 0,5333 \\
Z60 & 0,5333 & 0,4667 \\
Z80 & 0,7333 & 0,6667 \\
\hline
\end{tabular}

Statistical Evaluation Results for Abrasion

Resistance: Variance analysis was performed for the results obtained in the wear index values and the results of the variance analysis are given in Table 3. 
Table 3. Variance analysis results for wear index

\begin{tabular}{llccccc}
\hline & & $\begin{array}{c}\text { Sum of } \\
\text { squares }\end{array}$ & df & $\begin{array}{c}\text { Mean } \\
\text { Square }\end{array}$ & F & $\begin{array}{c}\text { Level of } \\
\text { importance }\end{array}$ \\
\hline \multirow{4}{*}{ Water-Based Ted } & Between Groups & 0,399 & 8 & 0,050 & 12,227 & 0,000 \\
\cline { 2 - 7 } & Within Groups & 0,073 & 18 & 0,004 & & \\
\cline { 2 - 7 } Actal & 0,472 & 26 & & & \\
\hline \multirow{3}{*}{ Acrylic Ted } & Between Groups & 0,173 & 8 & 0,022 & 10,324 & 0,000 \\
\cline { 2 - 7 } & Within Groups & 0,038 & 18 & 0,002 & & \\
& Total & 0,211 & 26 & & & \\
\hline
\end{tabular}

The Duncan test was performed for the homogeneity tests of the groups whose effects were investigated according to the varnish types according to the Duncan test results and the results are given below.

Duncan Test For Water-Based Varnish: Pigmented (TED) Duncan test results for abrasion resistance for synthetic varnish are given below.

Table 4. Abrasion index Duncan test results for pigmented (TED) samples for water based varnish.

\begin{tabular}{llllllll}
\hline GROUPS & N & $\mathbf{1}$ & $\mathbf{2}$ & $\mathbf{3}$ & $\mathbf{4}$ & $\mathbf{5}$ & $\mathbf{6}$ \\
\hline UV 20 & 3 &, 5333 & & & & & \\
Z60 & 3 &, 5333 & & & & & \\
Kontrol & 3 &, 6000 &, 6000 & & & & \\
PA5 & 3 &, 6333 &, 6333 &, 6333 & & & \\
PA5 & 3 & &, 7000 &, 7000 &, 7000 & & \\
Z80 & 3 & & &, 7333 &, 7333 &, 7333 & \\
MD15 & 3 & & & &, 7667 &, 7667 & \\
UV 10 & 3 & & & & &, 8333 &, 8333 \\
MD30 & 3 & & & & & &, 9000 \\
Level of importance & &, 094 &, 085 &, 085 &, 241 &, 085 &, 217 \\
\hline
\end{tabular}

According to the Duncan test results obtained, it was determined that the wear index value was collected in 6 different groups, the highest index value was in the samples with 30 seconds of microwave application and the lowest index value was in the 20 minutes of UV application. Statistically, it was determined that 15 seconds and 30 seconds of microwave application decreased the abrasion index value of all preliminary trials except the 80 numbered sandpaper.

Duncan Test For Water-Based Varnish: Pigmented (TED) Duncan test results for abrasion resistance for synthetic varnish are given below.

Table 5. Abrasion index Duncan test results on pigmented (TED) samples for acrylic varnish.

\begin{tabular}{lcccccc}
\hline GROUPS & $\mathbf{N}$ & $\mathbf{1}$ & $\mathbf{2}$ & $\mathbf{3}$ & $\mathbf{4}$ & $\mathbf{5}$ \\
\hline MD30 & 3 &, 3667 & & & & \\
Kontrol & 3 &, 4333 &, 4333 & & & \\
PA5 & 3 & &, 4667 &, 4667 & & \\
Z60 & 3 & &, 4667 &, 4667 & & \\
UV 10 & 3 & &, 5000 &, 5000 &, 5000 & \\
UV 20 & 3 & &, 5000 &, 5000 &, 5000 & \\
PA5 & 3 & & &, 5333 &, 5333 & \\
MD15 & 3 & & & &, 5667 & \\
Z80 & 3 & & & &, 6667 \\
Level of importance & &, 092 &, 125 &, 125 &, 118 & 1,000 \\
\hline
\end{tabular}

According to the results of Duncan test obtained, it was determined that the abrasion index value was collected in 5 different groups, the highest index value was in the samples with 80 sanding and the lowest index value was in the samples with 30 seconds of microwave application. Statistically, it was determined that 10 and 20 minutes of UV, 15 seconds of microwave, 80 number of sandpaper and $10 \%$ acid application increased the wear index value.

\section{CONCLUSION}

Wear index values of samples are given in Figure 2.

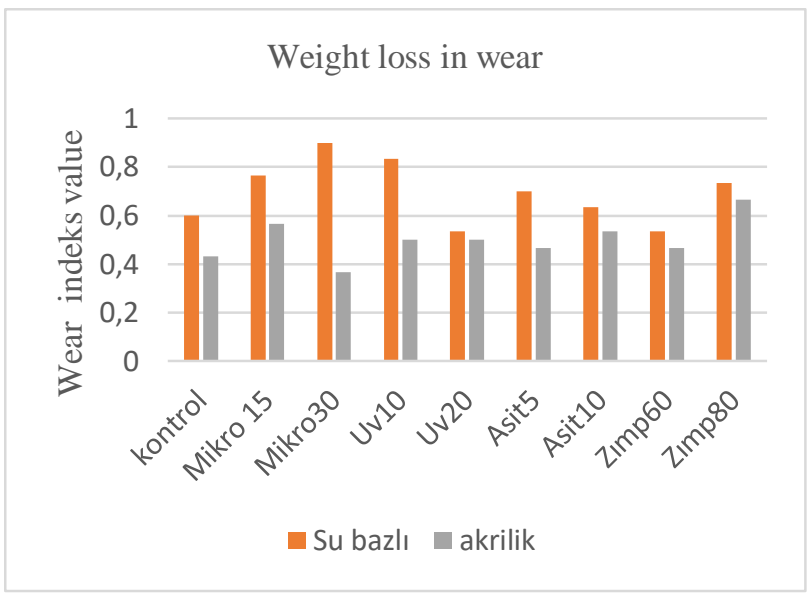

Figure 2. Abrasion index values

When the pigmented (TED) groups were examined, some pre-treatments increased the index value while others decreased it. When examined according to varnish types, the abrasion index value of acrylic varnish was low, while the highest was obtained in water-based varnish. It can be said that water-based varnishes wear easily.

\section{ACKNOWLEDGMENTS}

This study was carried out within the scope of TUBITAK 2140683 project and we thank TUBITAK for supporting the study. This study was presented in ORENKO 2020 held by Karadeniz Technical University, Trabzon.

\section{REFERENCES}

ASTM D 3359-09E2. (2002). Standard guide for evaluation of coatings applied to plastics. American Standard of Testing of Materials.

ASTM D 4060-10. (2010). Standard test method for abrasion resistance of organic coatings by the taber abraser. American Standard of Testing of Materials, 2010.

Barbosa, S.E. \& Kenny J. M. (2000). Processing of shortfiber reinforced polypropylene. I. Influence of processing conditions on the morphology of extruded filaments. Polymer Engineering Science, 40, 11-25.

Clemons, C.M., Caulfield, D.F. \& Giacomin, A.J. (1999). Dynamic fracture toughness of cellulose- 
fiber-reinforced polypropylene: Preliminary investigation of microstructural effects. Journal of Elastomer Plastics, 31, 367-378.

Novak, I. \& Florian, S. (2001). Influence of ageing on adhesive properties of polypropylene modified by discharge plasma. Polymer International, 50, 4952.

Ranby, B., Yang, W.T. \& Tretinnikov, O. (1999). Surface photografting of polymer fibers. films and sheets. Nuclear Instruments and Methods in Physics Research B, 151, 301-305.
Ryntz, R.A. (1998). Adhesion to plastics molding and paintability. Polymer Surfaces and Interfaces Series, Global Press.

Ryntz, R.A. (1994). Coating adhesion to low surface free energy substrates. Progress in Organic Coatings, 25, 73-83

Yang, W.T. \& Ranby, B. (1997). Bulk surface photografting process and its application III photolamination of polymer films. Journal of Applied Polymer Science, 63(13), 1723-1732. 